\title{
ANTICANCER ACTIVITY OF ZINC OXIDE AND ZINC OXIDE/CADMIUM SULFIDE NANOCOMPOSITES
}

\author{
ALI JABBAR JASIM MAKKAWI ${ }^{1}$, NOOR HADI AYSA ${ }^{2}$, FATTIMA-ALZAHRA G GASSIM ${ }^{2}$ \\ ${ }^{1}$ Department of Chemistry, Directorate of Education in Babylon, Ministry of Education, Iraq. ${ }^{2}$ Clinical Laboratory Sciences, College of \\ Pharmacy, University of Babylon, Iraq. Email: alijabbar064@gmail.com
}

Received: 26 March 2018, Revised and Accepted: 06 December 2018

\section{ABSTRACT}

Objective: The objective of this study is to investigate the anticancer activity of zinc oxide (ZnO) and ZnO/cadmium sulfide (CdS) nanoparticles ( $\mathrm{NPs}$ ). These NPs were active index against five human tumor cell lines, namely hepatocellular carcinoma, mammary gland (MCF-7), epidermoid carcinoma (HEP2), colorectal carcinoma (HCT-116), and rhabdomyosarcoma (RD).

Methods: $\mathrm{ZnO}$ and $\mathrm{ZnO} / \mathrm{CdS}$ NPs were synthesized using zinc acetate dihydrate and oxalic acid. The samples are characterized by Fourier-transform infrared spectroscopy, X-ray diffraction, scanning electron microscopy, energy-dispersive X-ray spectroscopy, and atomic force microscopy (AFM).

Results: The results were indicated that these NPs can be used to made drug delivery system depending on ZnO and ZnO/CdS nanocomposites for its potential role in enhancing the anticancer efficacy of doxorubicin as well as work on reducing side effects.

Conclusions: $\mathrm{ZnO}$ and $\mathrm{ZnO} / \mathrm{CdS}$ nanocomposites can be used anticancer for five human tumor cells.

Keywords: Medical applications of nanocomposites, Antitumor activity, Antioxidant activity.

(C) 2019 The Authors. Published by Innovare Academic Sciences Pvt Ltd. This is an open access article under the CC BY license (http://creativecommons. org/licenses/by/4. 0/) DOI: http://dx.doi.org/10.22159/ajpcr.2019.v12i2.26265

\section{INTRODUCTION}

Doxorubicin is one of the most one effective antitumor drugs in human cancers, comprising "acute lymphoblastic leukemia, breast carcinoma, ovarian carcinoma, and hepatocellular carcinoma (HEPG-2)" [1]. However, side effects make clinical application which is limited, and to overcome them, there should be new research method by changing biological distribution to target sites. Nanocomposites opened a new way to treatment by reducing side effects and using them in chemotherapy [2]. Zinc oxide ( $\mathrm{ZnO}$ ) nanocomposites can make significant contributions to the development of approaches of drug delivery in cancer and provide a platform for combined therapeutics with subsequent monitoring of response [3] are high efficient and non - toxic in addition to being stable at $\mathrm{PH}=7$, but solubility increases at $\mathrm{PH}>6$, and for easy arrived to the targeted sities[4]. This presses causes mitochondrial weaken which are produces " reactive oxygen species (ROS)", lipid peroxidation and DNA damage [5-7]. ZnO NPs are interacted with cancer cells rises from normal level, resulting in zinc-mediated protein activity disequilibrium. This affects a wide range of crucial cellular processes, including DNA replication, DNA damage repair, apoptosis, oxidation stress, electron transport chain, and cellular homeostasis, rendering cytotoxicity toward the cell [8]. ZnO-cadmium sulfide (CdS) NPs are important compounds for use in biomedical research, because of higher activity to anticancer and antimicrobial activities. In addition, it has been successfully used as drug delivery for loading and transport drugs to infected sites [9]. Several studies have suggested an increase in in vitro cytotoxicity with anaphase $\mathrm{ZnO}$ compared to micron-sized $\mathrm{ZnO}$ for several types of cancer including glioma, breast, bone, colon, and leukemias and lymphomas $[10,11]$. These studies showed the high degree of selective cancer cells, and killing them was depended on the proliferation status of cells, with rapidly dividing cells being the most susceptible [12]. Based on a growing body of evidence, ROS production is proposed as a key cytotoxic mechanism of ZnO NPs leading to cell death through an apoptotic mechanism [13]. ZnO exhibits biocompatibility. Therefore, Arakelova et al. [14] studied the action of ZnO NPs against MCF7 (human breast cell) and A549 (human lung cancer).

\section{METHODS}

Zinc acetate dehydrate, oxalic acid, and toluene were provided from China. Olic acid was supplied from Germany; thioacetamide and cadmium nitrate were purchased from HANNOVER. O-xylene was supplied from Washington.

\section{Preparation of ZnO NPs}

ZnO NPs were prepared by solving $22 \mathrm{~g}$ of zinc acetate with $600 \mathrm{ml}$ ethanol and heated to $60^{\circ} \mathrm{C}$ for $30 \mathrm{~min}$; $25.2 \mathrm{~g}$ oxalic acid was solved with $400 \mathrm{ml}$ ethanol and heated to $50^{\circ} \mathrm{C}$ and then mixed with the solvent above with the continuous stirring for $4 \mathrm{~h}$ then drying the thick solution at $80^{\circ} \mathrm{C}$ for $24 \mathrm{~h}$ to obtain nanopowder $\mathrm{ZnO}$ [15]. ZnO NPs were modified with oleic acid, as coupling agents, to modify their surface properties and make them more hydrophobic dispersible in the organic area.

\section{Preparation of $\mathrm{ZnO} / \mathrm{CdS}$ NPs}

The ZnO/CdS NPs were synthesized by immersed ZnO NPs into the clear reactant solution containing thioacetamide $(0.01 \mathrm{M}) \mathrm{C}_{2} \mathrm{H}_{5} \mathrm{NS}(0.01 \mathrm{M})$ and $\mathrm{Cd}\left(\mathrm{NO}_{3}\right)$ at room temperature for $15 \mathrm{~min}$. A yellow color precipitate of $\mathrm{ZnO} / \mathrm{CdS}$ was observed by adsorbing of $\mathrm{CdS}$ on the surface of $\mathrm{ZnO}$ NPs. A yellow sample was washed and filtrated by deionized water to remove the surface residue and finally dried at $90^{\circ} \mathrm{C}[16]$.

\section{Characterization}

ZnO NPs were characterized by scanning electron microscopy (SEM), energy-dispersive X-ray spectroscopy (EDS), atomic force microscopy, Fourier transform infrared spectroscopy (FT-IR) and X-ray diffraction (XRD).

\section{SEM}

SEM was used for observing the morphology of synthesized samples. Fig. 1 shows the SEM images of ZnO naked and modified NPs surface. The results showed highly agglomeration of ZnO NPs due to the surface energy that tends to clump together in large particles, and this agrees with the results of Xin [16]. It was found that the surface-modified 
ZnO NPs have reduced the agglomeration by reducing the energy of the surface. The results showed that the ZnO NPs were dispersed homogeneously after modification. Fig. 2 shows that the particle size was increased due to adhering of CdS NPs to the surface of ZnO NPs; the larger particles were the aggregates of smaller CdS NPs when a multilayer of CdS NPs was formed on the surface ZnO NPs.
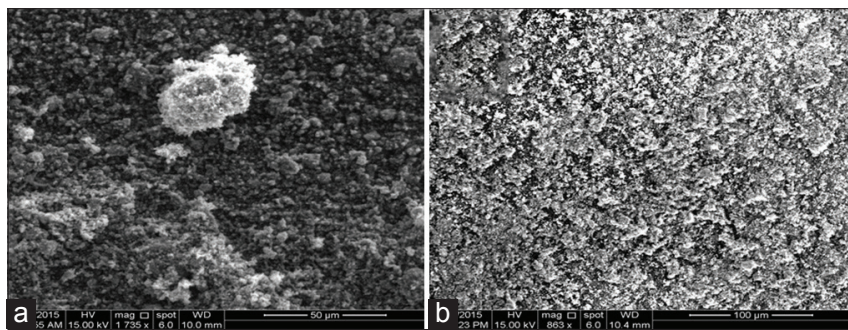

Fig. 1: Scanning electron microscopy images of (a) naked zinc oxide nanoparticles (ZnO NPs) and (b) modified ZnO NPs
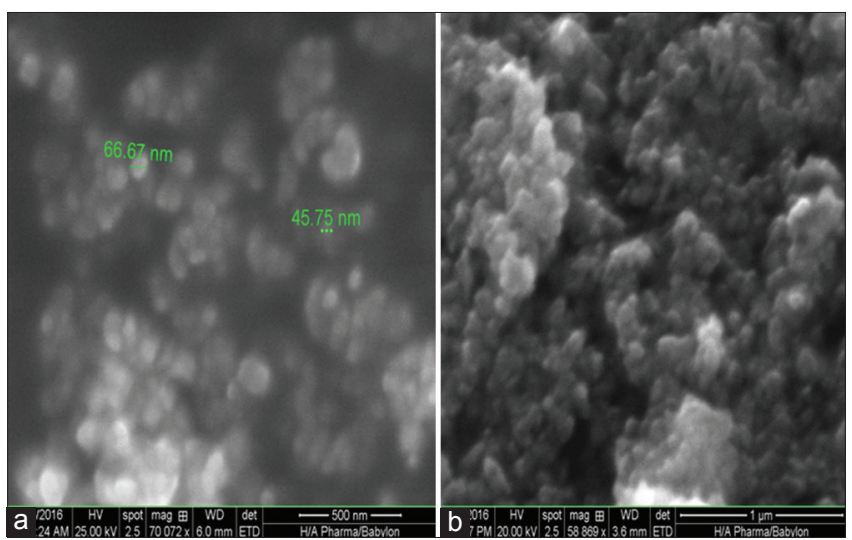

Fig. 2: (a and b) Scanning electron microscopy images of zinc oxide/cadmium sulfide nanocomposites
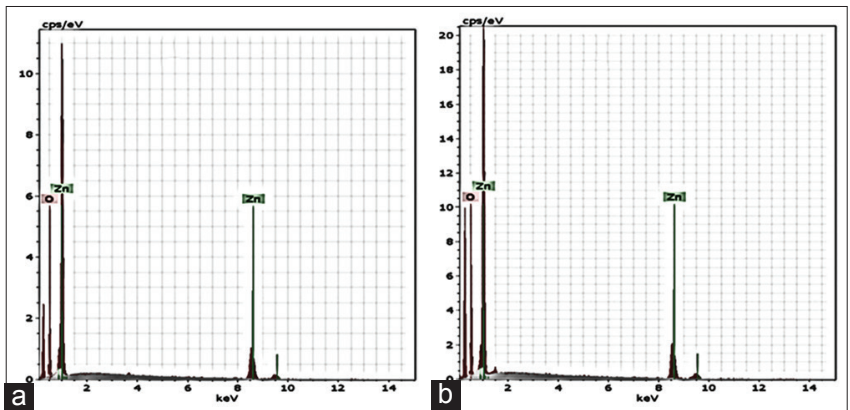

Fig. 3: (a and b) Energy-dispersive X-ray spectroscopy of (a) zinc oxide nanoparticles (ZnO NPs) naked and (b) ZnO NPs modified
EDS

The spectrum of EDS crystalline ZnO NPs is shown in Fig. 3. The purity of $\mathrm{ZnO}$ is $100 \%$ since there are no elements appeared in the spectrum and element analysis agrees with the researches [18].

\section{XRD analysis}

The XRD patterns of naked and unmodified ZnO NPs at a diffracted angle $\left(30^{\circ}-70^{\circ}\right)$ are illustrated in Fig. $4 \mathrm{a}$; a crystalline peak appeared which indicates crystalline structure at $2 \theta=34$, while a peak for modified $\mathrm{ZnO}$ at $2 \theta=36.569$. This indicates that crystalline material is prepared which agrees with the results of Zhang and Yang [19]. From the X-ray test

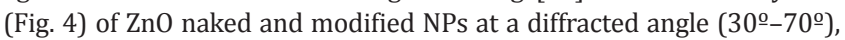
a crystalline peak appeared which indicates crystalline structure at $2 \theta=34$ and also a peak for modified $\mathrm{ZnO}$ at $2 \theta=36.569$. This indicates that crystalline material is prepared which agrees with the results of the Zhang and Hong $[19,20]$. XRD pattern of a $\mathrm{ZnO} / \mathrm{CdS}$ core shell NPs is shown in Fig. 4c where the diffraction peaks can be indexed to the spherical $\mathrm{ZnO}$ / CdS core shell structure. In total, seven diffraction peaks corresponding to the (100), (002), (101), (102), (110), (103), (200), (112) and (201) were related to the hexagonal crystal structure of $\mathrm{ZnO}$ [21].

Five human cancer cell lines namely; Hepatocellular carcinoma (HEPG2), Mammary gland (MCF-7), Epdermoid Carcinoma (HEP2), Colorectal carcinoma (HCT-116) and Rabdomyosarcoma (RD) were used to determine the antitumor activity of $\mathrm{ZnO}$ and $\mathrm{ZnO} / \mathrm{CdS}$ NPs. The cell lines were obtained from ATCC through Holding Company for Biological Products and Vaccines (VACSERA), Cairo, Egypt. Doxorubicin was used as a standard anticancer drug for comparison.

\section{Chemical reagents}

RPMI-1640 medium, MTT and DMSO (Sigma co., St. Louis, USA), Fetal Bovine serum (GIBCO, UK) were used as reagents.

\begin{abstract}
Antioxidant assays by ABTS
Antioxidant activity screening assay by ABTS method: For each of the investigated samples, $2 \mathrm{ml}$ of ABTS solution $(60 \mu \mathrm{M})$ was added to $3 \mathrm{ml} \mathrm{MnO}_{2}$ suspension $(25 \mathrm{mg} / \mathrm{ml})$, in aqueous phosphate buffer solution ( $\mathrm{pH} 7,0.1 \mathrm{M})$. The mixture was shaken, centrifuged, and filtered and the absorbance of the resulting green blue solution (ABTS radical solution) at $734 \mathrm{~nm}$ was adjusted to approx. ca. 0.5. Then, $50 \mu \mathrm{l}$ of $2 \mathrm{~m} \mu$ solution of the tested sample in spectroscopic grade $\mathrm{MeOH}$ :phosphate buffer (1:1) was added. The absorbance was measured and the reduction in color intensity was expressed as inhibition percentage. L-ascorbic acid was used as standard antioxidant (positive control). Blank sample was run without ABTS and using $\mathrm{MeOH} /$ phosphate buffer (1:1) instead of tested samples. Negative control was run with ABTS and MeOH:phosphate buffer (1:1) only [22,23]. The free radical inhibition percentage of each sample was calculated as follows:
\end{abstract}

$\operatorname{ABTS}(\%$ inhibition $)=\operatorname{Abs}($ control $)-A b s($ test $) /$ Abs $($ control $) \times 100$

\section{RESULTS AND DISCUSSION}

Cytotoxicity assessment of $\mathrm{ZnO}$ and $\mathrm{ZnO}$-CdS nanocomposites, against human tumor cells HePG2, HCT-116, MCF-7, RD, and HeP2

Table 1: In vitro $\mathrm{IC}_{50}$ of $\mathrm{ZnO}$ and $\mathrm{ZnO-CdS}$ nanocomposites against human tumor cells HePG2, HCT-116, MCF-7, RD and HeP2 compared to doxorubicin

\begin{tabular}{llllll}
\hline \multirow{2}{*}{ Compound } & \multicolumn{2}{l}{ In vitro cytotoxicity $\mathrm{IC}_{\mathbf{5 0}}(\boldsymbol{\mu g}) \cdot \boldsymbol{l}$} & & \\
\cline { 2 - 6 } & HePG2 & HCT-116 & MCF-7 & RD & HeP2 \\
\hline DOX•• & $4.50 \pm 0.2$ & $5.23 \pm 0.3$ & $4.17 \pm 0.2$ & $6.10 \pm 0.4$ & $8.54 \pm 0.6$ \\
ZnO & $33.23 \pm 3.2$ & $37.09 \pm 3.8$ & $29.50 \pm 2.7$ & $47.08 \pm 4.1$ & $20.53 \pm 2.3$ \\
ZnO/CdS & $9.26 \pm 1.0$ & $5.64 \pm 0.4$ & $7.90 \pm 0.8$ & $9.51 \pm 0.9$ & $10.17 \pm 1.1$ \\
\hline
\end{tabular}

$\mathrm{IC}_{50}(\mu \mathrm{g})$ : 1-10 (very strong). 11-20 (strong). 21-50 (moderate). 51-100 (weak) and above 100 (non-cytotoxic). • DOX: Doxorubicin, ZnO: Zinc oxide, CdS: Cadmium sulfides 


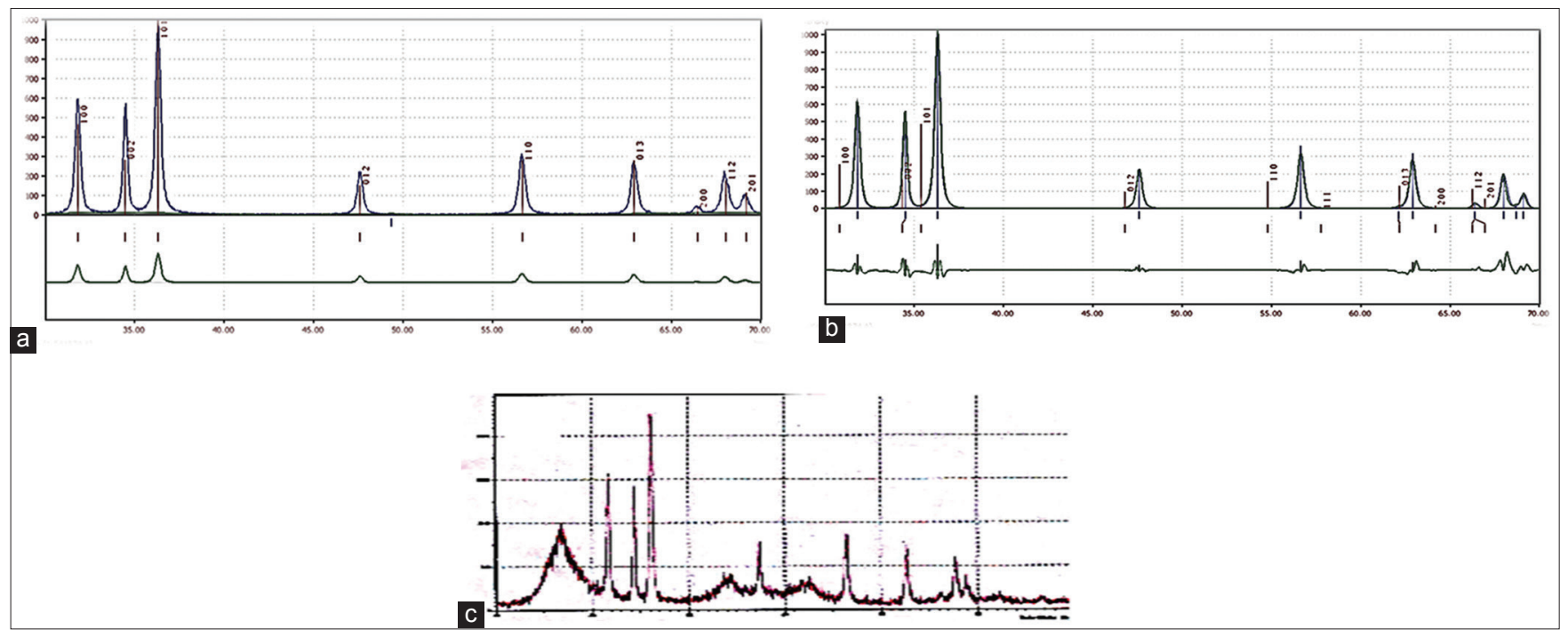

Fig. 4: Analysis of X-ray diffraction for (a) zinc oxide (ZnO) unmodified nanoparticles (NPs), (b) ZnO modified NPs, and (c) ZnO/cadmium sulfide nanocomposites Cell line

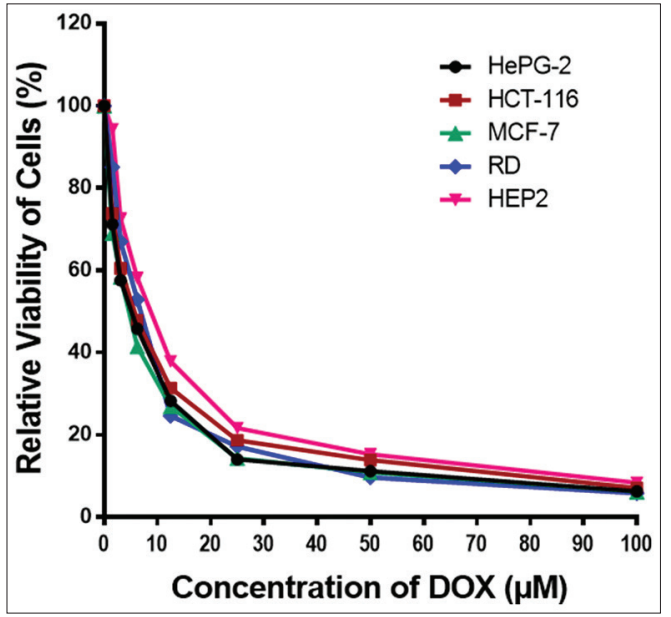

Fig. 5: The relative viability human cancer cells (\%) to the concentration of doxorubicin $(\mu \mathrm{M})$

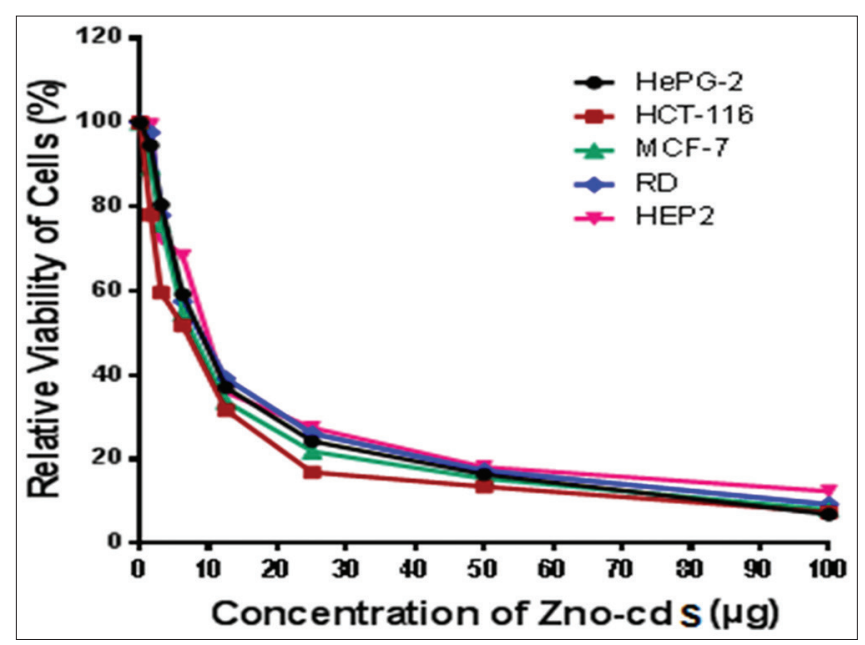

Fig. 6: The relative viability human cancer cells (\%) to the concentration of zinc oxide-cadmium sulfide nanocomposites $(\mu \mathrm{g})$

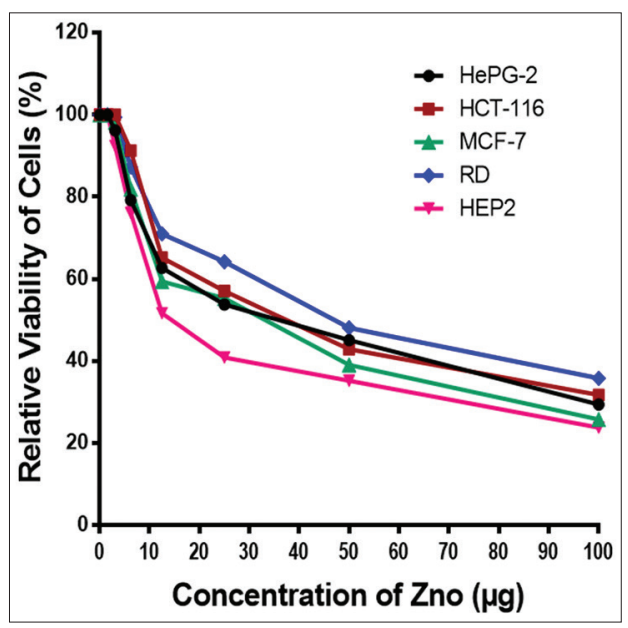

Fig. 7: The relative viability human cancer cells (\%) to the concentration of zinc oxide nanoparticles $(\mu \mathrm{g})$

Table 2: $\mathrm{IC}_{50}$ values of $\mathrm{ZnO}$ NPs and $\mathrm{ZnO} / \mathrm{CdS}$ nanocomposites by ABTS, compared to ascorbic acid

\begin{tabular}{lll}
\hline Compounds & Absorbance of samples & \% Inhibition \\
\hline Control of ABTS & 0.505 & 0 \\
Ascorbic-acid & 0.455 & 88.5 \\
ZnO & 0.482 & 6.4 \\
ZnO/CdS & 0.442 & 14.2 \\
\hline
\end{tabular}

ZnO: Zinc oxide, CdS: Cadmium sulfides, NPs: Nanoparticles

The results of Table 1 were indicated that the in vitro cytotoxicity $\mathrm{IC}_{50}(\mu \mathrm{g} / \mathrm{ml})$ to all five types of tumor cancer was moderate for $\mathrm{ZnO}$ NPs, while the in vitro cytotoxicity $\mathrm{IC}_{50}(\mu \mathrm{g} / \mathrm{ml})$ to HePG2, HCT-116, MCF-7, and RD was very strong and $\mathrm{HeP} 2$ was strong for $\mathrm{ZnO} / \mathrm{CdS}$ nanocomposites [24].

Recent development in cancer research suggests that a number of apoptotic stimuli shares common mechanistic pathway characterized by the generation of ROS. The mechanism of cytotoxicity from $\mathrm{ZnO}$ 
NPs is not completely understood, The mechanism of cytotoxicity from ZnO NPs was deepened on the generation of ROS through oxidative stress [22]. ROS typically include the superoxide, the hydrogen peroxide, and the hydroxyl radical which causes damage to cellular component such as lipids, DNA, and proteins and eventually leads to cell death [25]. In agreement with previous reports, it was found that the ZnO NPs induced the generation of ROS in the cancer cells, whereas normal astrocytes exhibited lower levels of ROS in response to the ZnO NPs. Figs. 5-7 demonstrate the relative viability human cancer cells (\%) with different concentrations of $\mathrm{ZnO} \mathrm{NPs}$ and $\mathrm{ZnO} / \mathrm{CdS}$ nanocomposites, respectively. The results show that the relative viability human cancer cells (\%) were decreased with increase of NPs due to the increasing interaction of cancer cell NPs [26].

Table 1 illustrates that the anticancer activity was increased using $\mathrm{ZnO} / \mathrm{CdS}$ nanocomposites instead of ZnO NPs. This observation can be explained that the band gap energy of $\mathrm{ZnO}$ is approximately $3.2 \mathrm{eV}$ [27]. Coupling ZnO partials with narrow bandgap semiconductors such as CdS can be utilized bang gap ZnO to visible light. Decreasing of band gap energy causes increasing the ability of NPs to produce ROS which causes damage to cancer cellular components [28].

\section{Antioxidant activity assessment}

Free radical scavenging method (ABTS)

The free radicals of " 2 , 2'-azino-bis (3-ethylbenzthiazoline-6-sulphonic acid)" (ABTS) were used for exposure of the antioxidant activity of $\mathrm{ZnO}$ NPs and ZnO/CdS nanocomposites. The decrease in color intensity was expressed as inhibition percentage $[29,30]$. The lower the percentage inhibition, the higher the antioxidant scavenging activity. The results of antioxidant activity are illustrated in Table 2.

This assay is based on the ability of ABTS to be decolorized in the presence of antioxidants. The corresponding ABTS radical scavenging activity was used for detection of the antioxidant activity. $\mathrm{ZnO} / \mathrm{CdS}$ nanocomposites was the most active [30]. ZnO NPs caused decreased antioxidant enzyme activities as an antioxidant agent by inhibiting the formation of ROS and scavenging the free radicals [32]. Oxidative stress plays a major role in the etiology of several diabetic complications. NPs are also being explored for use in intracellular delivery of DNA, RNA, proteins, peptides, and small drugs for inducing cancer cell death, as contrast agents for cancer imaging, and as platforms for targeted gene and chemotherapeutics delivery to tumor sites [33]. The results refers the effect of the ZnO NPs on cancer cells results from the ROS generated which leads to an increase sensitivity of these cells to oxidative stress [33,34].

\section{CONCLUSIONS}

ZnO NPs and ZnO-CdS NPs were synthesized and characterized by various techniques, including XRD, SEM, Fourier-transform infrared and UV-visible (DRS). Anticancer activity and antioxidant activity screening assay ABTS of the NPs were examined using five human cancer cells (HEPG-2, MCF-7, HEP2, HCT-116, and RD). The effect of the NP concentrations on the cancer cells was determined, and the mechanisms of treatment with the $\mathrm{ZnO}$ and $\mathrm{ZnO} / \mathrm{CdS}$ nanocomposites was depended on the generation of ROS.

\section{AUTHORS' CONTRIBUTIONS}

Nicked ZnO NPs and identify this NPs which has been synthesized by Dr. Noor Hadi Aysa Coupled ZnO/CdS NPs, and identify these NPs which has been synthesized by Dr. Fattima-Alzahara G. Gassiam. Biological activity of two NPs ( $\mathrm{ZnO}$ and $\mathrm{ZnO} / \mathrm{CdS}$ ) has been done by Dr. Ali J. J. Makkawi, introduction and anticancer results have been written by Dr. Ali J. J. Makkawi, while discussion the results and references have been written by Dr. Fattima-Alzahara G. Gassiam and Dr. Noor Hadi Aysa.

\section{CONFLICTS OF INTEREST}

Authors declared no conflicts of interest.

\section{REFERENCES}

1. Jeong YI, Kim DH, Chung CW, Yoo JJ, Choi KH, Kim CH, et al. Doxorubicin-incorporated polymeric micelles composed of dextran-b-poly(DL-lactide-co-glycolide) copolymer. Int J Nanomedicine 2011;6:1415-27.

2. Zheng J, Lee HC, Bin Sattar MM, Huang Y, Bian JS. Cardioprotective effects of epigallocatechin-3-gallate against doxorubicin-induced cardiomyocyte injury. Eur J Pharmacol 2011;652:82-8.

3. Liong M, Lu J, Kovochich M, Xia T, Ruehm SG, Nel AE, et al. Multifunctional inorganic nanoparticles for imaging, targeting, and drug delivery. ACS Nano 2008;2:889-96.

4. Selvakumari D, Deepa R, Mahalakshmi V, Subhashini P, Lakshminarayan N. Anticancer activity of ZnO nanoparticles on MCF7 (breast cancer cell) and A549 (cancer cell). ARPN J Eng Appl Sci 2015;10:5418-21.

5. Yousefpour P, Atyabi F, Farahani EV, Sakhtianchi R, Dinarvand R. Polyanionic carbohydrate doxorubicin-dextran nanocomplex as a delivery system for anticancer drugs: In vitro analysis and evaluations. Int J Nanomedicine 2011;6:1487-96.

6. Ibsen S, Zahavy E, Wrasdilo W, Berns M, Chan M, Esener S, et al. A novel doxorubicin prodrug with controllable photolysis activation for cancer chemotherapy. Pharm Res 2010;27:1848-60.

7. Chahal A, Saini AK, Kumar A, Saini RV. Natural antioxidants as defense against cancer. Asian J Pharm Res 2018;11:38-44.

8. Mishra PK, Mishra H, Ekielski A, Talegaonkar S, Vaidya B. Zinc oxide nanoparticles: A promising nanomaterial for biomedical applications. Drug Discov Today 2017;22:1825-34.

9. Guo D, Wu C, Jiang H, Li Q, Wang X, Chen B, et al. Synergistic cytotoxic effect of different sized $\mathrm{znO}$ nanoparticles and daunorubicin against leukemia cancer cells under UV irradiation. J Photochem Photobiol B 2008;93:119-26.

10. Wang H, Wingett D, Engelhard MH, Feris K, Reddy KM, Turner P, et al. Fluorescent dye encapsulated $\mathrm{znO}$ particles with cell-specific toxicity for potential use in biomedical applications. J Mater Sci Mater Med 2009;20:11-22.

11. Yadav V. Nanotechnology, big things from a tiny world: A review. Int J Serv Sci Technol 2013;3:771-8

12. Lin W, Xu Y, Huang CC, Ma Y, Shannon KB, Chen DR, et al. Toxicity of nano-and micro-sized $\mathrm{ZnO}$ particles in human lung epithelial cells. J Nanopart Res 2009;11:25-39.

13. Arakelova ER, Grigoryan SG, Arsenyan FG, Babayan NS, Grigoryan RM, Sarkisyan NK. In vitro and in vivo anticancer activity of nanosize zinc oxide composites of doxorubicin. Int J Biomed Pharm Sci 2014;8:1.

14. Litter ML, Navio JA. Un usual photo reactivity of zinc oxide irradiated by concentrated sun light. J Photochem Photobiol A Chem 1994;79:131.

15. Chica A, Gatti G, Moden B, Marchese L, Iglesia E. Selective catalytic oxidation of organosulfur compounds with tert-butyl hydroperoxide. Chemistry 2006;12:1960-7.

16. Xin JH, Yeo SY, Lee HJ, Jeong SH. Preparation of nano composite fibres for permanent antibacterial effect. J Mater Sci 2003;38:2143-7.

17. Gnanasangeetha D, Thambwani DS. Biogenic production of zinc oxide nanoparticlesusing Acalypha indica. J Chem Biol Phys Sci 2013;1:238-46.

18. Spolenak R, Ludwig W, Buffiere JY, Michler J. In-situ elastic strain measurements-diffraction and spectroscopy. MRS Bull 2010;35:368-74.

19. Zhang F, Yang J. Preparation of nano-ZnO and its application to the textile on antistatic finishing. Int J Chem 2009;1:18-22.

20. Rasal S, More PV, Hiragond C, Jadhav S, Khanna PK. Rapid homogenization method for synthesis of core/shell $\mathrm{ZnO} / \mathrm{CdS}$ nanoparticles and their photocatalytic evaluation. Adv Mater Lett 2016;7:390-7

21. Kahn ML, Monge M. Size-and shape-control of crystalline zinc oxide nanoparticles: A new organometallic synthetic method. Adv Funct Mater 2005;3:458-68.

22. Kavithar R. Antidiabetic and enzymatic antioxidant potential from ethanolic extracts of leaf and fruit of Trichosanthes dioica and leaf of Clitoria ternatea on diabetic rats induced by streptozotocin. Asian J Pharm Clin Res 2018;11:233-9.

23. El-Gazar A, Adams B, YoussefYM,Abu-HashemAA, Badria FA. Design and synthesis of azolopyrimidoquinolines, pyrimidoquinazolines as anti-oxidant, anti-inflammatory and analgesic activities. J Med Chem 2009; $44: 609-24$

24. Aeschlach R, Loliger J, Scott CB, Murcia A, Butler JB, Halliwell IO. Antioxidant actions of thymol, carvacrol, 6-gingerol, zingerone and hydroxytyrosol. Food Chem Toxicol 1994;32:31-6.

25. Pal S, Tak YK, Song JM. Does the antibacterial activity of silver nanoparticles 
depend on the shape of the nanoparticle? A study of the gram-negative bacterium Escherichia coli. Appl Environ Microbiol 2007;73:1712-20.

26. Huang K, Ma H, Liu J, Huo S, Kumar A, Wei T, et al. Size-dependent localization and penetration of ultrasmall gold nanoparticles in cancer cells, multicellular spheroids, and tumors in vivo. ACS Nano 2012;6:4483-93.

27. Rasmussen JW, Martinez E, Louka P, Wingett DG. Zinc oxide nanoparticles for selective destruction of tumor cells and potential for drug delivery applications. Expert Opin Drug Deliv 2010;7:1063-77.

28. AL-Zahra AF, Alkhateeb A, Hussin F. Photocatalytic oxidation of benzyl alcohol using pure and sensitized anatase. Desalination 2007;209:342-9.

29. AL-Zahra AF, Azize HW, Jassim AJ. Sterilization of waste water from Staphylococcus aureaus bacteria by using $\mathrm{TiO}_{2}$. Int J Chem 2013;2:386-91 .

30. Arya P. Antioxidant, phytochemical and antibacterial action of Himalayan medicinal herbs Peristrophe bicalyculata leaves extract against respiratory tract pathogens. Int J Pharm Pharm Sci 2018;10:16-21.
31. Lissi E, Modak B, Torres R, Escobar J, Urza A. Total antioxidant potential of resinous exudates from Heliotropium species, and a comparison of the ABTS and DPPH methods, Free Radic Res 1999;30:471-7.

32. Shaaban S, Negm A, Sobh MA, Wessjohann LA. Organoselenocyanates and symmetrical diselenides redox modulators: Design, synthesis and biological evaluation. Eur J Med Chem 2015;97:190-201.

33. Barathmanikanth S, Kalishwaralal K, Sriram M, Pandian SR, Youn HS, Eom S, et al. Anti-oxidant effect of gold nanoparticles restrains hyperglycemic conditions in diabetic mice. J Nanobiotechnology 2010;8:16.

34. Brannon-Peppas L, Blanchette JO. Nanoparticle and targeted systems for cancer therapy. Adv Drug Deliv Rev 2004;56:1649-59.

35. Shaji J, Shaikh M. Drug-resistant tuberculosis: Recent approach in polymer based nanomedicine resistant tuberculosis. Int J Pharm Pharm Sci 2016;8:1-6. 